\title{
THE LATER RAMSAY
}

A SUPPLEMENTARY BIBLIOGRAPHY OF THE PUBLISHED WRITINGS OF SIR WILLIAM MITGHELL RAMSAY

$$
\text { By c. J. HEMER }
$$

Several recent writers have called attention to the unhappy neglect of the achievement of Sir William Mitchell Ramsay, ${ }^{1}$ even though his indirect influence has permeated British scholarship, especially with regard to the Acts of the Apostles. His later reputation both as apologist and controversialist has cast a shadow over his whole personality and work.

The bibliography attached to the Festschrift Anatolian Studies Presented to Sir William Mitchell Ramsay, ed. W. H. Buckler and W. M. Calder (Manchester, I923), is a most valuable tool for the study both of the antiquities of Asia Minor and of the New Testament. There is also some valuable material and a selective topical bibliography of Ramsay's principal works in the recent study by W. Ward Gasque. But there is no systematic list available of the writings of his last years, between I923 and his death in 1939 .

These were not Ramsay's best or his most productive years. Many of his faults are seen at their plainest in them. Sharp insights are mingled with discursive speculations. He returns obsessively and argumentatively to old themes like the South Galatian debate. He did not mellow with age: in commenting on the publications of a colleague who had offended him he writes: 'They rank as the worst epigraphic articles that the world has ever seen.'

One cannot, however, afford to neglect the later Ramsay. His mastery of his material is the fruit of sixty years of the study of inner Anatolia. And these writings, with all their

${ }^{1}$ F. F. Bruce, The Acts of the Apostles, ${ }^{2}$ Tyndale Press, London (1952) viii; S. Neill, The Interpretation of the New Testament 186I-196r, OUP, London (1964) 145; W. W. Gasque, Sir William M. Ramsay. Archaeologist and New Testament Scholar, Baker Book House, Grand Rapids (1964) 10. 
faults, are almost exclusively concerned with the archaeology and epigraphy of Asia Minor, the field in which his competence could not be questioned. They are incidentally very rich in their illumination of the world of the New Testament. And even his book reviews are frequently the vehicle for detailed epigraphical discussions.

The present bibliography is arranged in three parts. In the first I have placed for convenience some bibliographical and biographical notices of Ramsay by others. The second part is occasioned by the discovery that the list of his works compiled by his daughter in 1923, extensive as it is, is incomplete. In particular it omits several series of contributions to the $E x$ pository Times in the years immediately preceding. The final section listing the later writings is the main reason for this paper. It is very unlikely to be anywhere near complete, for Ramsay made many excursions into current affairs and social questions, scattered habitually in magazines and newspapers where they would not repay the labour of tracing them. But I hope I have included all, or almost all, his academic works. I have searched the later issues of many periodicals to which he had contributed previously, in most cases without success.

\section{Abbreviations}

\begin{tabular}{ll} 
Byz & Byzantion \\
CF & The Classical Journal \\
CR & The Classical Reviere \\
Expos & The Expositor \\
ExpT & The Expository Times \\
Fahresh & Fahreshefte des österreichischen archäologischen In- \\
\multicolumn{1}{|c}{ stituts in Wien } \\
FHS & Journal of Hellenic Studies \\
$\mathcal{F R S}$ & Journal of Roman Studies \\
SST & The Sunday School Times \\
TLZ & Theologische Literaturzeitung
\end{tabular}

(A) BIOGRAPHICAL AND BIBLIOGRAPHIGAL REFERENGES

A. Margaret Ramsay, 'A List of the Published Writings of Sir William Mitchell Ramsay', Anatolian Studies Presented to 
Sir William Mitchell Ramsay, ed. W. H. Buckler and W. M. Calder, Manchester U.P. (I923) xiii-xxxviii.

H. Grégoire, 'Sir William Ramsay', Byz 6 (r931) v-xii.

W. F. Howard, Romance of New Testament Scholarship, Epworth, London (1949) I38-I55, reprinted from Religion in Life 8 (1939) 580-590.

W. W. Gasque, Sir William M. Ramsay, Archaeologist and New Testament Scholar. A Survey of his Contribution to the Study of the New Testament (Baker Studies in Biblical Archaeology), Baker Book House, Grand Rapids (rg66).

(B) SUPPLEMENTARY BIBLIOGRAPHY OF RAMSAY'S WRITINGS TO I923

I893

'De Galatia Romana Provincia', TLZ I8 (1893) 506-507. I897

'Traveling in the Time of St. Paul: Its Possibilities and Popularity', SST 39 (1897) 371-372.

'The Phrygian Inscriptions and the Book of Acts', SST 39 (1897) 626-627.

1898

Paulus in der Apostelgeschichte. In deutscher Übersetzung von H. Groschke, Bertelsmann, Gütersloh (1898).

1904

Note on J. Ghapman, 'The Seven Churches of Asia', Expos, 6 th ser. 9 (1904) 263-265.

rgro

'The Authorities for the Institution of the Eucharist', $\operatorname{Exp} T$ 2 I (I909-10) 246-252, 295-298, 343-347, 473-477, 5I5-5I9. 1912

'What were the Churches of Galatia?' $\operatorname{Exp} T$ 24 (1912-13) I9-22, 6I-63, I 22-125.

I9I 3

'What were the Churches of Galatia?' (concluded) ExpT 24 (I912-13) 219-223, 280-283, 331-333, 378-379, 47I-473, $563-566$. 
I9I5

'The Old Testament in the Roman Phrygia', ExpT 26 (I9I4-I5) I68-I 74 [including material on personal names and dialectal Greek].

IgI6

'The Denials of Peter', ExpT 27 (I9I5-I6) 296-301, 360363, 410-4I3, 47I-472, 540-542 [including excursus 'The House in the New Testament' re Troas, etc., pp. 47I-472].

I9I7

'The Denials of Peter' (concluded), ExpT 28 (I9r6-r7) 276-28I.

'The Leaf-Ramsay Theory of the Trojan War', CF I3 (I9I7г8) $69-7$ г.

I9I8

'The Family and Religion of L. Sergius Paullus, Proconsul of Cyprus', $\operatorname{ExpT} 29$ (I9I 7-18) 324-328.

(c) RAMSAY'S WRITINGS AFTER I923

1924

'Note on the Angora Resolution', $\mathcal{F H S} 44$ (I924) I62.

'Studies in the Roman Province Galatia. VI. Some Inscriptions of Colonia Caesarea Antiochea', 7RS I4 (I924) I 72-205.

\section{925}

'The Simile of the Vultures in the Odyssey', GJ 20 (I 924-5) 363 .

'The Simile of the Vultures in the Odyssey. Second Note', CJ 2 I (I925-6) 40-4I.

I 926

'Studies in the Roman Province Galatia. VII. Pisidia. VIII. Map of Yallowadj. IX. Inscriptions of Antioch of Phrygiatowards-Pisidia (Colonia Caesarea)', $7 R S$ I6 (I926) I02-I I9. 'X. The Romans in Galatia', ibid. 20I-2I5.

1927

Asianic Elements in Greek Civilisation (The Gifford Lectures in the University of Edinburgh, I9I5-16), Murray, London (I927), pp. xi, 303 . 
Monumentum Antiochenum. Die neugefundene Aufzeichnung der Res Gestae Divi Augusti im pisidischen Antiochia, ed. W. M. Ramsay and A.von Premerstein, Klio Beiheft 19, Dieterich'sche Verlagsbuchhandlung, Leipzig (1927), pp. x, I2I, I5 plates.

'A Scene from the Anatolian Mysteries', $\mathcal{F H S ~} 47$ (1927) I80-I8I.

'Zum Streit um das Monumentum Antiochenum. II. Sir William Mitchell Ramsay's Entgegnung', Klio 21 (1927) $435-436$.

1928

'Anatolica Quaedam. I. The Campaigns of Servius Isauricus in Asia Minor. II. A Salve for Wounds. III. Neon, Nikon and Heliodorus', $\mathcal{J H S} 48$ (I928) 46-53.

'Roman Garrisons and Soldiers in Asia Minor' (with A. M. Ramsay), FRS I8 (I928) I8I-19o.

I929

'Res Anatolicae. I. The Elimination of Lake Trogitis (SeidiSheher). II. Oroanda: Ager Oroandicus: Tractus Oroandicus', Klio 22 (1929) 269-283.

'Roman Soldiers and Garrisons in Asia Minor. Part II', JRS I9 (I929) I55-16o.

I930

'Anatolica Quaedam. IV. Head of Augustus Mourning (Pisidian Antioch). V. Medical Prescriptions at Holy Places. VI. The Image of Caesar: and the Amazons. VII. The Site of Isaura Nova. VIII. Street Signs in Anatolian Cities. IX. An Invented Cult of King Attalos. X. Temples in Anatolia. XI. The People of Lairbenos', $7 H S$ 5o (1930) 263-287.

'A Doubtful Inscription', Klio 23 (I930) 20-23 [Iconium]. 'Trogitis or Soghla-Göl (Marsh-Lake), also called SeidiSheher-Göl, Kara-Viran-Göl', Klio 23 ( I 930) 98-99.

'Res Anatolicae. III. Ecce Iterum Pisidia', Klio 23 (I930) 239-255.

I93 I

'Phrygian Orthodox and Heretics (400-800 A.D.)', Byz 6 (I93 I) I-35.

1932

'Mystery of a Doubtful Inscription', Klio 25 (I932) 422-427 [Iconium]. 
'Tyraion', CR 46 (1932) I54-155, 203.

'The Date of St. Polycarp's Martyrdom', Jahresh 27 (1932) Beiblatt, 245-258.

1933

'Bishop Lightfoot', Theology 26 (I933) 75-82 [Galatian controversy].

Review Corpus Notitiarum Episcopatuum Ecclesiae Orientalis Graecae. I Band: 'Die Genesis der Notitia Episcopatuum', ed. E. Gerland, Socii Assumptionistae Chalcedonenses, KadiKeui (r931), $\mathcal{F H S} 53$ (1933) I55-157.

Review Supplementum Epigraphicum Graecum Vol. VI, Sijthoff, Leyden (1932), JHS 53 (1933) 313-318.

I934

'Neryllinus', $C R 48$ (1934) 9-13 [Troas]. 1936

Review, H. Swoboda et al., Denkmäler aus Lykaonien, Pamphylien, und Isaurien, Rohrer, Brno (1935), JHS 56 (I936) 257-26r.

Review, Corpus Notitiarum Episcopatuum Ecclesiae Orientalis Graecae, Vol. I, Part II, ed. E. Gerland, revised and completed by V. Laurent, Socii Assumptionistae Chalcedonenses, KadiKeui (1936), $\mathcal{F H S} 5^{6}$ (1936) 272-273.

I937

'Note on JHS r937, p. r', $\mathcal{F H S} 57$ (r937) 247. 1939

'Early History of Province Galatia', Anatolian Studies Presented to William Hepburn Buckler, ed. W. M. Calder and J. Keil, Manchester U.P. (I939) 20I-225 (I. Era. 2. Military Equipment. 3. Dea Julia Augusta. 4. Early Legati. 5. The War for Taurus. 6. Memory of Augustus. Appendix I. Pre-Provincial Galatia. II. [A Palaeographical Note].)

'Galatia', International Standard Bible Encyclopaedia, Eerdmans, Grand Rapids (I939), II. I I54-I I55.

I94I

The Social Basis of Roman Power in Asia Minor, prepared for the press by J. G. G. Anderson, Aberdeen U.P. (I94I), pp. xii, 305 . 